\title{
ANALISIS MINAT BELI KONSUMEN SABUN CAIR LUX, BIORE DAN LIFEBUOY DI KOTAMADYA YOGYAKARTA DITINJAU DARI PENGARUH SIKAPNYA SETELAH MELIHAT IKLAN DI TELEVISI DAN NORMA SUBYEKTIF
}

\author{
Albari \& Anita Liriswati \\ Fakultas Ekonomi Universitas Islam Indonesia
}

\begin{abstract}
Abstrak
Salah satu program pemasaran yang intensitasnya semakin gencar dilakukan berupa periklanan merek di media televisi, termasuk pada sabun cuci cair. Kegiatan ini dimaksudkan untuk mempengaruhi minat konsumen untuk membeli, baik melalui sikap konsumen dan atau norma subyektif. Oleh karena itu penelitian ini dilakukan dengan menggunakan Reasoned Action Model yang dianggap representatif mampu mengungkap minat beli konsumen.

Populasi penelitian adalah konsumen potensial yang sudah pernah melihat iklan sabun cair merek Lux, Biore dan Lifebuoy di televisi Data penelitian diperoleh melalui dua tahap penyebaran angket dan dilakukan secara convenience sampling dan area random sampling. Hipotesis diuji melalui pendekatan uji-beda Friedman, serta analisis regresi dan koefisien determinan yang dikuatkan dengan uji-t dan uji-F pada taraf signifikansi 5\%.

Hasil penelitian menunjukkan bahwa 10 atribut produk sabun cair dan empat kelompok referen relevan dijadikan sebagai dasar analisis. Di samping itu ada perbedaan keyakinan konsumen bahwa membeli sabun cair merek Lux, Biore atau Lifebuoy menimbulkan akibat tertentu. Perbedaan juga terjadi pada keyakinan normatif konsumen. Secara umum faktor evaluasi lebih dominan berpengaruh positif terhadap sikap konsumen dibandingkan dengan keyakinan konsumen. Pengaruh positif dari keyakinan normatif konsumen dan atau motivasi untuk mengikuti referen terhadap norma subyektif menunjukkan hasil yang berbeda-beda, dan tidak ada pengaruh positif sikap dan norma subyektif terhadap minat konsumen untuk membeli sabun cair Lux, Biore atau Lifebuoy.
\end{abstract}

Keyword: Sikap, norma subyektif, minat membeli

\section{PENDAHULUAN}

Pemasaran modern memerlukan lebih dari sekedar mengembangkan produk yang baik, menawarkannya dengan harga yang menarik, dan membuatnya mudah didapat oleh pelanggan sasaran. Perusahaan harus juga mengembangkan suatu program komunikasi yang efektif dengan para pelanggan yang ada dan pelanggan potensial, pengecer, pemasok, pihak-pihak yang memiliki kepentingan pada produk tersebut, dan masyarakat umum.

Salah satu program komunikasi adalah promosi. Promosi merupakan salah satu elemen dari marketing mix yang dipakai perusahaan untuk memasarkan produknya. Periklanan merupakan salah satu dari alat promosi yang paling umum digunakan perusahaan untuk menginformasikan, membujuk, dan mengingatkan pembeli sasaran atau masyarakat. Inti dari periklanan adalah untuk memasukkan sesuatu ke dalam pikiran kon- 
sumen, mengubah persepsi konsumen, dan mendorong konsumen untuk bertindak (Kotler, 2003). Dan salah satu media promosi dalam bentuk periklanan adalah Televisi (TV). TV mempunyai kemampuan kuat untuk mempengaruhi, bahkan membangun persepsi khalayak sasaran dan konsumen lebih percaya pada perusahaan yang mengiklankan produknya di TV daripada yang tidak sama sekali (Mittal, 1994).

Salah satu iklan yang sering muncul di TV adalah iklan sabun cair. Meskipun hanya menguasai $10 \%$ pasar sabun, namun sabun cair diyakini sebagai produk masa depan yang menggiurkan. Puluhan merek pun bersaing ketat berebut pasar senilai Rp 150 miliar per tahun (Manopol, 2001). Sabun cair semakin diminati konsumen di Indonesia karena pertama, sabun cair lebih praktis. Kedua, lebih higienis - karena produk yang sama tidak dipakai secara bergantian oleh beberapa orang. Ketiga, sabun cair lebih modern. Tiga merek yang bersaing ketat di antara puluhan merek sabun cair adalah Lux, Biore, dan Lifebuoy.

Berdasarkan data AC Nielsen Indonesia pada akhir 2000 (Manopol, 2001), biaya total iklan yang dikeluarkan oleh Lux cair sebesar Rp 4,2 miliar, Rp 4,19 miliar untuk iklan TV dan sisanya untuk iklan majalah. Biore Body Foam with deodorant dan Biore Antiseptic sama sekali tidak menjatah iklan di koran dan majalah. Kecuali, Biore Extra Mild yang mengalokasikan Rp 43 juta untuk iklan di majalah dari total dana sebesar Rp 2,8 miliar. Sementara itu Lifebuoy cair sama sekali tidak menampilkan iklannya di majalah atau koran, tetapi hanya menggunakan media TV. Lebih lanjut data riset Mars tahun 2000 (Manopol, 2001) menunjukkan konfigurasi pasar sabun cair adalah Lux cair sekitar 32,9\%, Biore 29,95\%, Lifebuoy cair $19,74 \%$, sedangkan sisanya adalah produk sabun cair pendatang baru seperti Nuvo cair, Pucelle, Gatsby dan merek yang lain.

Iklan-iklan sabun cair tersebut masing-masing dikemas sedemikian menariknya agar konsumen yang melihat iklan tersebut di TV tertarik untuk mengikuti iklan dari awal hingga akhir. Semakin banyak dan lengkapnya informasi produk/merek yang disampaikan melalui iklan, maka semakin besar pula rasa ingin tahu konsumen tentang produk/merek, yang kemudian akan menimbulkan minat dalam diri konsumen untuk membeli produk/merek tersebut. Demikian pula yang diharapkan akan terjadi pada konsumen sabun cair, mereka akan menjadi berminat membeli sabun cair setelah melihat iklan sabun cair merek tertentu.

\section{KERANGKA TEORITIS DAN HIPOTESIS PENELITIAN}

Salah satu model untuk memahami minat konsumen untuk membeli produk adalah Behavioral Intention Model (Model Minat Berperilaku) atau Reasoned Action Model dari Fishbein dan Ajzen. Minat berperilaku 
adalah suatu proporsi yang menghubungkan diri dengan tindakan yang dilakukan di waktu yang akan datang. Dalam model ini minat konsumen tidak hanya dilihat dari sikap konsumen terhadap obyek, melainkan juga melihat pada norma subyektif yang mempertimbangkan persepsi seseorang terhadap tanggapan orang yang dekat dengannya apabila ia berperilaku tertentu (Loudon dan Della Bitta, 1993). Kedua faktor tersebut dianggap penting, disebabkan karena sikap seorang individu relatif stabil dan tidak berubah dari waktu ke waktu, sedangkan orang lain secara langsung berkaitan dengan keputusan-keputusan pembelian dan menjadikan seseorang dapat mengidentifikasikan dirinya dengan kelompok tertentu (Pride dan Ferrel, 1995).

Lebih lanjut Dharmmesta (1992) menyatakan bahwa, pertama, model ini mengungkapkan bahwa perilaku berasal dari formasi keinginan spesifik untuk berperilaku. Jadi model keinginan berperilaku tidak berusaha memprediksikan perilaku seseorang, tetapi keinginan untuk bertindak. Kedua, model ini mencakup bentuk baru yang disebut norma subyektif. Norma subyektif menilai seseorang yang dipercaya konsumen bahwa orang lain akan berpikir mereka harus melakukannya. Dengan kata lain, norma subyektif memperkenalkan formulasi pengaruh kelompok referensi yang sangat kuat terhadap perilaku.

Perubahan ketiga dari model ini mencakup obyek sikap diarahkan. Selain menilai sikap konsumen terhadap sebuah merek, model ini juga menilai sikap konsumen terhadap perilaku pembelian. Perbedaan penting di sini adalah bahwa fokusnya terletak pada persepsi konsumen tentang konsekuensi dari pembelian yang akan terjadi. Penilaian konsekuensi pembelian apakah produk memiliki atau tidak memiliki atribut tertentu dapat membantu para peneliti mempertimbangkan faktor-faktor yang menghalangi keinginan konsumen untuk berperilaku.

Bertitik tolak dari informasi sejumlah konsumen melalui analisis sikap dan norma subyektif, pemasar dapat mengetahui minat konsumen dalam membeli, dapat memberikan arahan dalam bentuk produk dan pelayanan kebutuhan konsumen yang lebih baik. Sikap adalah kecenderungan yang dipelajari untuk bereaksi terhadap penawaran produk dalam masalah yang baik ataupun kurang baik secara konsisten (Swastha dan Irawan, 1997). Sikap menguraikan evaluasi, perasaan, dan kecenderungan diri seseorang terhadap suatu obyek serta menempatkan seseorang dalam suatu kerangka pemikiran mengenai menyukai-tidak menyukai atau mendekati-menjauhi suatu obyek tertentu.

Adapun norma subyektif merupakan kecenderungan yang dipelajari dari konsumen melalui keyakinannya bahwa referen berpikir tentang sesuatu yang akan dilakukan oleh konsumen (Schiffman dan Kanuk, 1997). Referen merupakan kelompok di sekitar konsumen (orang lain penting) 
ketika konsumen mengidentifikasikan dirinya dengan kelompok tersebut, sehingga konsumen mengambil banyak nilai, sikap, atau perilaku para anggota kelompok. Karena itu referen dapat berupa anggota keluarga, teman, sahabat, atasan, bawahan dan seorang ahli.

Dari penjelasan-penjelasan tersebut Wells dan Prensky (1996) kemudian melakukan formulasi Reasoned Action Model seperti yang nampak pada Gambar 1.

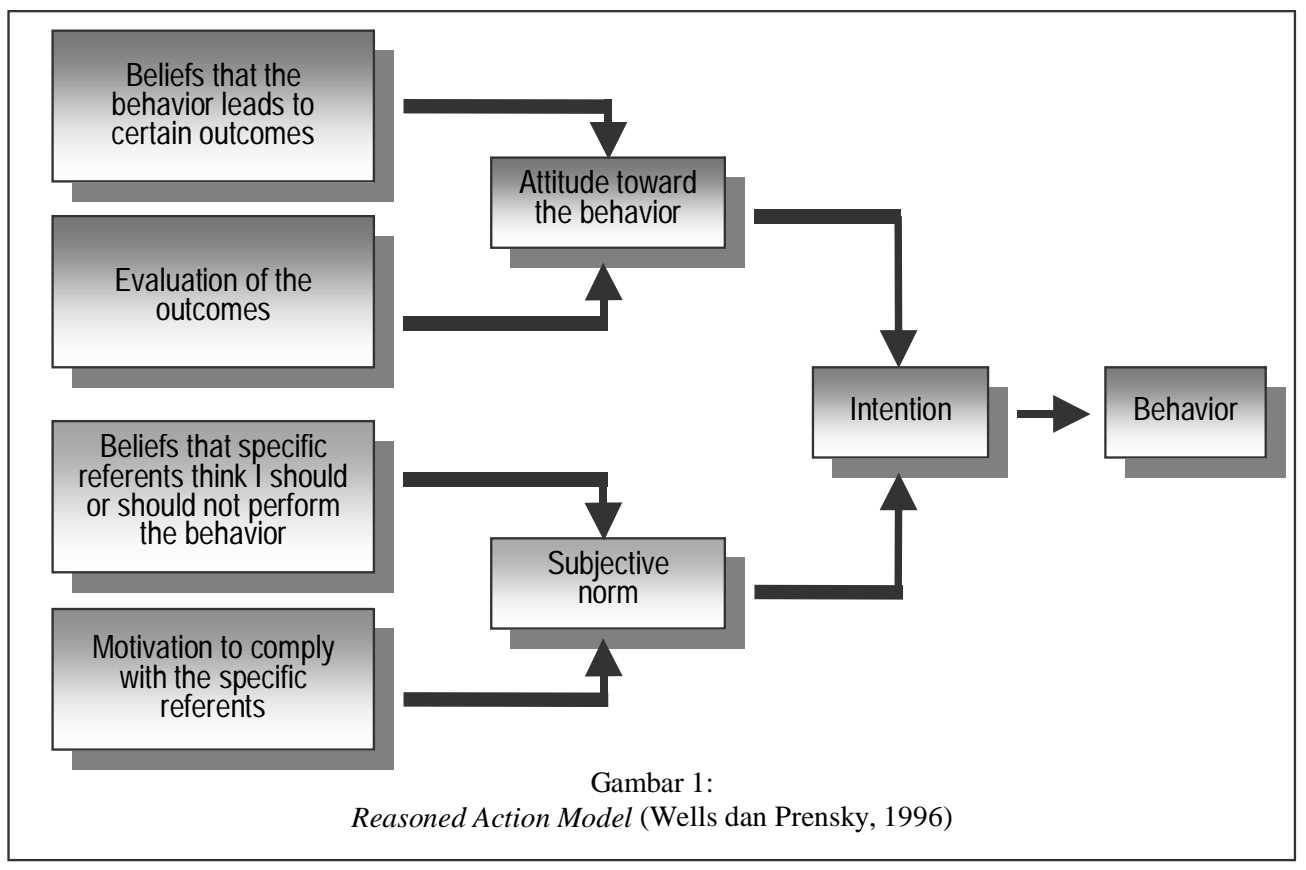

Gambar 1 tersebut mununjukkan bahwa perilaku konsumen dapat diprediksi oleh minatnya untuk berperilaku. Sedangkan minat berperilaku konsumen dapat dipengaruhi oleh sikapnya untuk berperilaku dan atau norma subyektif. Adapun sikap konsumen ditentukan oleh keyakinan bahwa perilaku menyebabkan akibat tertentu dan atau evaluasi pada akibat perilaku. Sementara norma subyektif dapat dipengaruhi langsung oleh keyakinan konsumen bahwa referen tertentu berpikir konsumen akan atau tidak akan melakukan perilaku tertentu dan atau motivasi untuk menuruti referen tertentu.

Di samping bentuk seperti model di atas, Reasoned Action Model juga dapat dirumuskan secara matematis seperti yang dijelaskan oleh Mowen dan Minor (1998) sebagai berikut: 


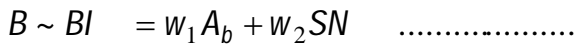

$$
\begin{aligned}
& A_{b} \quad=\sum_{i=1}^{n} b_{i} e_{i} \\
& \text { SN } \quad=\sum_{j=1}^{m} N B_{j} M C_{j}
\end{aligned}
$$

untuk:

$\mathrm{B}=$ = Perilaku tertentu;

$\mathrm{BI} \quad=$ Minat berperilaku;

$\mathrm{A}_{b} \quad=$ Sikap ke arah pelaksanaan perilaku;

$\mathrm{w}_{1}, \mathrm{w}_{2}=$ Bobot regresi yang ditentukan secara empiris;

$\mathrm{b}_{\mathrm{i}} \quad=$ Keyakinan seseorang bahwa pelaksanaan perilaku menimbulkan akibat i

$\mathrm{e}_{\mathrm{i}} \quad=$ Evaluasi seseorang tentang akibat $\mathrm{i}$;

SN = Norma subyektif;

$\mathrm{NB}_{\mathrm{j}} \quad=$ Keyakinan normatif bahwa kelompok atau seorang referen $\mathrm{j}$ berpikir konsumen sebaiknya atau sebaiknya tidak melaksanakan perilaku;

MC $_{\mathrm{j}} \quad=$ Motivasi untuk menuruti pengaruh dari referen $\mathrm{j}$;

$n \quad$ = Banyaknya keyakinan

$\mathrm{m} \quad$ = Banyaknya kelompok referen yang relevan;

tanda = menunjukkan bahwa kedua variabel, B dan BI, dapat berhubungan.

Persamaan (1) menyatakan bahwa berperilaku merupakan fungsi dari evaluasi keseluruhan tentang sikap terhadap perilaku $A_{b}$, ditambah keyakinan tentang pengharapan-pengharapan dari orang penting (referen) lain terhadap perilaku seperti itu, yang kemudian ditimbang dengan motivasinya untuk menuruti pengharapan-pengharapan tersebut (norma subyektif); dan minat berperilaku itu sendiri akan menentukan perilakunya.

Persamaan (2) meggambarkan kombinasi antara kekuatan keyakinan konsumen $\left(b_{i}\right)$ dan evaluasinya $\left(e_{i}\right)$ untuk membentuk sikap ke arah perilakunya. Dan dari persamaan (3) dapat diketahui bahwa norma subyektif konsumen terbentu dari hasil keyakinan konsumen bahwa orang penting lain berpendapat sebaiknya atau tidak sebaiknya melaksanakan perilaku $B\left(\mathrm{NB}_{\mathrm{j}}\right)$ dengan motivasi konsumen untuk menuruti pengharapan-pengharapan sosial itu (MCj).

Persamaan (2) tersebut juga memberi petunjuk bahwa perubahan evaluasi dan keyakinan akan berpengaruh secara positif terhadap sikap, artinya semakin besar evaluasi dan atau keyakinan konsumen, maka semakin besar pula sikap konsumen untuk berperilaku. Demikian pula yang terjadi untuk persamaan (3), yakni semakin besar keyakinan normatif dan 
atau motivasi konsumen untuk menuruti referen, semakin besar (berpengaruh positif) pula terhadap norma subyektifnya.

Dalam ilustrasi penelitian tentang pilihan merek-merek produk dengan menggunakan Reasoned Action Model ini (misalnya Loudon dan Della Bitta, 1993; Moven dan Miror, 1998; serta Wells dan Prensky, 1996) untuk mengetahui sikap, pengukuran evaluasi konsumen merujuk pada baik-buruk atau penting-tidak pentingnya atribut produk yang relatif identik dan menurut konsumen harus terdapat pada merek-merek yang ada, sehingga lebih bersifat generik (umum) yang semua merek akan mempunyainya. Sedangkan untuk keyakinan menunjuk secara spesifik kepada atribut produk yang dipunyai merek tertentu dan yang akan diperoleh konsumen jika mereka berperilaku membeli merek tersebut. Dengan kata lain atribut produk pada evaluasi dan keyakinan pada dasarnya sama. Jadi, jika terdapat atribut produk sebanyak (i) dan jumlah merek produk adalah (n), maka pengukuran evaluasi akan sebanyak (i) tetapi pengukuran keyakinan akan sejumlah (in). Penjelasan yang sama juga berlaku pada norma subyektif, yaitu penjelasan evaluasi untuk motivasi menuruti referen tertentu serta keyakinan konsumen untuk keyakinan normatif.

Di muka telah disebutkan bahwa Reasoned Action Model dapat dipergunakan untuk memprediksi tentang perilaku konsumen melalui minat berperilaku. Hal ini dengan asumsi bahwa ada korelasi yang kuat antara ukuran minat dengan ukuran perilaku. Dalam riset pemasaran, pengukuran minat berperilaku perlu dilakukan segera sebelum pengukuran perilaku dilakukan.

Di samping itu untuk memprediksi perilaku secara akurat maka kondisi tertentu yang spesifik, yang ditunjukkan oleh ukuran-ukuran dari ke dua variabel itu harus menunjukkan dengan jelas adanya hubungan dalam hal (Dharmmesta, 1992):

\ Tindakan yang menjadi acuan,

- Sasaran kearah tindakan itu diarahkan,

- Konteks tindakan itu terjadi, dan

a Waktu tindakan itu dilakukan.

Kondisi-kondisi dari ke empat hal tersebut harus maksimal adalah merupakan persyaratan agar dapat diperoleh korelasi yang kuat antara minat dan perilaku. Perhatian terbesar terutama ditujukan pada interval waktu antara pengukuran minat dengan perilaku tersebut, karena jika waktunya terlalu panjang, maka intervensi situasional atau faktor antara pengukuran keduanya akan sangat berpengaruh terhadap perilaku yang diharapkan. Intervensi situasional tersebut dapat berupa perubahan kondisi ekonomi, politik, hukum, atau munculnya kesempatan baru untuk membelanjakan uang. 
Secara aplikatif penelitian konsumen yang mendasarkan pada Reasoned Action Model dari Fishbein dan Ajzen ini sudah banyak dilakukan, di antaranya oleh Haerani (1993), Kristianto (1994), dan Wardani (1994). Dalam penelitiannya, Haerani (1993) dan Kristianto (1994) melakukan analisis sampai dengan variabel minat untuk berperilaku. Hal ini berarti bahwa kedua orang tersebut menganggap minat untuk berperilaku dapat dipakai untuk memprediksi perilaku beli konsumen yang diteliti. Sedangkan pada penelitian Wardani ((1994), perilaku beli konsumen diukur langsung dengan pernyataan responden melalui jawaban pada angket yang diedarkan dalam tenggang waktu kurang lebih satu bulan sesudah angket pertama.

Dari uraian di atas, maka penelitian guna mengungkapkan sikap konsumen tentang atribut manfaat produk yang diiklankan di TV dan norma subyektif yang dapat mempengaruhi minat beli konsumen pada 3 merek utama sabun cair (Lux, Biore dan Lifebuoy) perlu dilakukan, sehingga dapat dijadikan masukan untuk perbaikan dalam bauran produk dan strategi pemasaran yang akan diputuskan oleh perusahaan yang memproduksi sabun cair.

Lebih jauh hasil penelitian ini diharapkan dapat membuktikan hipotesis sebagai berikut:

$\boldsymbol{H}_{1}$ : Ada perbedaan keyakinan konsumen bahwa membeli sabun cair merek Lux, Biore, atau Lifebuoy menimbulkan akibat tertentu ( $\left.b_{i}\right)$

$\mathrm{H}_{2}$ : Ada perbedaan keyakinan normatif bahwa kelompok atau seorang referen $j$ berpikir konsumen sebaiknya atau sebaiknya tidak membeli sabun cair merek Lux, Biore, dan Lifebuoy ( $\left.N B_{j}\right)$.

$\boldsymbol{H}_{3}$ : Ada pengaruh positif keyakinan konsumen $\left(b_{i}\right)$ dan evaluasi $\left(e_{i}\right)$, baik secara individu maupun secara serentak, terhadap sikap konsumen $\left(A_{b}\right)$ untuk membeli sabun cair merek Lux, Biore, atau Lifebuoy;

$\mathrm{H}_{4}$ : Ada pengaruh positif keyakinan normatif $\left(N B_{j}\right)$ dan motivasi untuk mengikuti referen $\left(M C_{j}\right)$, baik secara individu maupun secara serentak, terhadap norma subyektif konsumen (SN) untuk membeli sabun cair merek Lux, Biore, atau Lifebuoy;

$H_{5}: \quad$ Ada pengaruh positif sikap konsumen $\left(A_{b}\right)$ dan norma subyektif ( $\left.S N\right)$, baik secara individu maupun secara serentak, terhadap minat konsumen untuk membeli (I) sabun cair merek Lux, Biore, atau Lifebuoy.

\section{METODE PENELITIAN}

\section{Subyek Penelitian dan Pengumpulan Data}

Subyek penelitian ini adalah masyarakat atau konsumen potensial yang berdomisili di Kotamadya Yogyakarta, dan yang sudah pernah melihat ketiga iklan produk sabun cair Lux, Biore, dan Lifebuoy di televisi, tetapi belum pernah membeli ketiga produk sabun cair tersebut. Sedangkan data diperoleh melalui 2 (dua) tahap penyebaran angket kepada sampel penelitian. 
Angket pertama disebarkan kepada 20 orang secara convenience sampling, yaitu dengan memberikan angket kepada sampel konsumen yang mudah ditemui dari kriteria populasi di atas. Angket ini diedarkan untuk mengidentifikasi atribut penting yang diyakini konsumen dan orang lain penting yang menjadi referensi konsumen yang berpengaruh terhadap minat beli konsumen terhadap sabun cair, sehingga dapat digunakan sebagai dasar penyusunan angket kedua. Atribut dan referen penting yang dimintakan pertimbangannya kepada konsumen tersebut tanpa membedakan merek sabun cair yang ada serta menggunakan sistem setengah terbuka. Jawaban yang diberikan diukur dengan menggunakan skala interval empat ruas yang berjajar dari sangat tidak setuju sampai sangat setuju.

Dari angket pertama tersebut dapat diperoleh hasil tentang atribut penting yang diyakini konsumen harus diperoleh dalam membeli sabun cair adalah: menghaluskan kulit, membersihan kulit, menyehatkan kulit, mengharumkan kulit, meningkatkan percaya diri, menciptakan citra diri yang baik, ekonomis pemakaian, harga yang murah, praktis dipakai, praktis disimpan dan produk yang awet. Sedangkan referen yang dianggap penting yang dapat mempengaruhi pembelian konsumen adalah: keluarga (ibu/adik/kakak/sepupu), teman dekat (sahabat/pacar), rekan kerja (sekolah/kampus/kantor) dan dokter kulit.

Untuk angket kedua pengambilan sampel ditentukan melalui dua tahap. Tahap pertama adalah menentukan tiga kecamatan di Kotamadya Yogyakarta di antara 13 kecamatan yang ada secara area random sampling, sehingga dapat diperoleh representasi tiga kecamatan, yaitu Kecamatan Umbulharjo, Kecamatan Gondokusuman, dan Kecamatan Kotagede. Tahap kedua yaitu menyebarkan angket kepada 100 penduduk di ketiga kecamatan tersebut secara convenience sampling, yaitu konsumen yang mudah ditemui dan belum pernah membeli sabun cair Lux, Biore, dan Lifebuoy, tetapi yang telah melihat ketiga iklan sabun cair tersebut di TV.

Angket kedua ini pada dasarnya digunakan untuk memperoleh data pokok untuk keperluan analisis, yang terdiri dari butir-butir pertanyaan yang berhubungan dengan faktor-faktor keyakinan (11 butir), evaluasi (11 butir), keyakinan normatif (4 butir), motivasi konsumen (4 butir), dan minat konsumen dalam membeli sabun cair (1 butir). Di samping itu, karena setiap butir pertanyaan pada bagian faktor-faktor keyakinan dan keyakinan normatif masing-masing terdiri dari tiga kelompok jawaban, yaitu untuk merek Lux, Biore, dan Lifebuoy, maka keseluruhan jawaban pertanyaan menjadi 63 butir.

Jawaban atas pertanyaan-pertanyaan dari variabel tersebut diukur dengan menggunakan skala interval empat ruas mulai dari sangat setuju, setuju, tidak setuju, dan sangat tidak setuju dengan bobot nilai masingmasing sebesar 2,1, -1, dan -2 . 
Uji validitas dilakukan dengan menggunakan pendekatan Pearson Correlation, sedangkan uji reliabilitas memakai Alpha Cronbach. Data yang ada kemudian diolah dengan menggunakan program SPSS pada taraf signifikansi $5 \%$. Hasil pengujian menunjukkan bahwa semua butir pernyataan dalam kondisi valid dan reliabel, sehingga data angket kedua dapat digunakan untuk analisis tanpa perlu mengalami perubahan isi.

\section{Metode Analisis Data.}

Analisis data yang dilakukan didasarkan pada Reasoned Action Model dari Fishbein dan Ajzen. Namun untuk dapat menjawab pertanyaan penelitian dengan baik dipergunakan Uji Beda Friedman dan Analisis Regresi.

Uji Beda Friedman dipilih untuk membuktikan hipotesis pertama dan kedua, yaitu untuk membuktikan ada-tidaknya perbedaan keyakinan penting konsumen bahwa membeli merek sabun cair merek Lux, Biore, dan Lifebuoy akan menerima konsekuensi atribut $\mathrm{i}\left(\mathrm{b}_{\mathrm{i}}\right)$ serta keyakinan normatif kepada referen konsumen dalam membeli sabun cair tersebut $\left(\mathrm{NB}_{\mathrm{j}}\right)$. Uji beda dilakukan untuk masing-masing atribut (i) sabun cair dan masingmasing referen (j) konsumen. Di samping itu, Uji beda hanya meliputi dua variabel tersebut, karena keduanya sebagai dasar yang dapat digunakan untuk membedakan variabel sikap, norma subyektif dan minat pada tahapan analisis berikutnya dari ketiga merek sabun cair yang ada.

Analisis Regresi digunakan untuk membuktikan hipotesis penelitian ketiga sampai kelima, yaitu untuk menetapkan ada-tidaknya variabelvariabel yang mempengaruhi sikap, norma subyektif dan minat beli konsumen. Analisis Regresi akan dilengkapi dengan Koefisien Determinan dari model regresi sederhana/parsial $\left(r^{2}\right)$ maupun model regresi ganda/serentak $\left(R^{2}\right)$, sehingga dapat diketahui proporsi variabel terikat yang dapat dijelaskan oleh nilai-nilai variabel bebas. Pengertian variabel-variabel tersebut mengacu pada Reasoned Action Model, selain setiap analisis yang dilakukan mendasarkan pada masing-masing atribut atau referen konsumen serta untuk masing-masing merek sabun cair yang diteliti. Di samping itu, agar hasil analisis menjadi bermakna perlu dilakukan prosedur pengujian dengan pendekatan uji-t (parsial) dan uji-F (serentak).

\section{HASIL DAN PEMBAHASAN}

Untuk memudahkan pembahasan dan analisis, hasil penelitian dikelompokkan ke dalam bentuk tabel. Tabel 1 berisi hasil perhitungan dengan menggunakan pendekatan Uji Beda Friedman yang disajikan dengan mencantumkan keyakinan konsumen untuk menerima konskuensi atribut $\mathrm{i}\left(\mathrm{b}_{\mathrm{i}}\right)$, referen penting $\mathrm{j}\left(\mathrm{NB}_{\mathrm{j}}\right)$ konsumen, taraf signifikansi hitung (sig) 
dan status uji beda kritisnya. Tabel 2 mencantumkan referen penting $\mathrm{j}\left(\mathrm{NB}_{\mathrm{j}}\right)$ konsumen, taraf signifikansi hitung (sig) dan status uji beda kritisnya.

Sedangkan Tabel 3, yang berupa hasil perhitungan Analisis Regresi dan Koefisien Determinan berisi sikap konsumen $(A)$ untuk masingmasing atribut, koefisien variabel keyakinan $\left(b_{i}\right)$ dan evaluasi keyakinan (e), serta nilai koefisien determinan. Tabel 4 memuat Norma Subyektif (SN) masing-masing referen penting konsumen, koefisien keyakinan normatif $\left(\mathrm{NB}_{\mathrm{j}}\right)$ dan motivasi untuk mengikuti referen $(\mathrm{MC})$, serta nilai koefisien determinan. Adapun Tabel 5 menginformasikan minat berperilaku konsumen (BI), sikap, norma subyektif dan koefisien determinan.

\section{Uji Beda Friedman}

Hasil Uji Friedman yang dilakukan untuk menjelaskan adatidaknya perbedaan keyakinan penting konsumen bahwa membeli merek sabun cair merek Lux, Biore, atau Lifebuoy akan menerima akibat atribut i $\left(b_{i}\right)$ atau untuk menguji hipotesis pertama ditunjukkan pada Tabel 1.

Tabel 1:

Hasil Uji Friedman Keyakinan

\begin{tabular}{|l|c|c|}
\hline Atribut & Sig & Keterangan \\
\hline Penghalus Kulit & 0.000 & Signifikan \\
\hline Pembersih Kulit & 0.000 & Signifikan \\
\hline Penyehat Kulit & 0.000 & Signifikan \\
\hline Pengharum Kulit & 0.000 & Signifikan \\
\hline Meningkatkan PD & 0.000 & Signifikan \\
\hline Citra diri jadi baik & 0.136 & Tdk signifikan \\
\hline Ekonomis dipakai & 0.000 & Signifikan \\
\hline Harga yang murah & 0.023 & Signifikan \\
\hline Praktis dipakai & 0.000 & Signifikan \\
\hline Praktis disimpan & 0.000 & Signifikan \\
\hline Awet & 0.000 & Signifikan \\
\hline
\end{tabular}

Sumber: Data diolah

Dari Tabel 1 dapat diketahui bahwa dari sebelas uji beda keyakinan tentang atribut manfaat membeli sabun cair semuanya memberikan hasil yang signifikan, kecuali pada atribut manfaat membuat citra diri jadi baik (karena tingkat signifikansi uji lebih besar dari 5\%). Dengan demikian hipotesis pertama untuk sepuluh manfaat menggunakan sabun cair terbukti, yang berarti terdapat perbedaan keyakinan penting konsumen bahwa membeli merek sabun cair merek Lux, Biore, dan Lifebuoy akan menerima konsekuensi atribut-atribut tersebut. Kesepuluh atribut manfaat tersebut akan dipergunan sebagai dasar analisis selanjutnya (analisis regresi), se- 
dangkan untuk manfaat sabun cair yang membuat citra diri baik, karena secara statistika terbukti tidak mempunyai perbedaan pada bagian selanjutnya tidak akan diikutsertakan dalam analisis regresi.

Adapun hasil perhitungan Uji Beda Friedman untuk keyakinan normatif konsumen sekaligus untuk menguji hipotesis kedua dapat diringkas dalam Tabel 2:

Tabel 2:

Hasil Uji Friedman Keyakinan Normatif

\begin{tabular}{|l|c|c|}
\hline \multicolumn{1}{|c|}{ Referen } & Sig & Keteranagan \\
\hline Keluarga & 0.000 & Signifikan \\
\hline Teman dekat & 0.000 & Signifikan \\
\hline Rekan kerja & 0.000 & Signifikan \\
\hline Dokter kulit & 0.000 & Signifikan \\
\hline
\end{tabular}

Sumber: Data diolah

Dari Tabel 2 dapat dilihat bahwa semua referen hasilnya signifikan karena tingkat signifikansinya lebih kecil dari 5\% (0.05), yang artinya bahwa ada perbedaan keyakinan normatif konsumen atas semua referen yang ditanyakan dari ketiga merek sabun cair Lux, Biore, dan Lifebuoy. Oleh karena keempat referen tersebut untuk selanjutnya akan dipergunakan sebagai dasar model analisis regresi norma subyektif.

\section{Analisis Regresi dan Koefisien Determinan}

Analisis hasil penelitian pada bagian ini meliputi 3 (tiga) tahapan prosedur, yaitu menetapkan nilai positif koefisien faktor keyakinan konsumen dan evaluasi keyakinan atau norma subyektif dan motivasi mengikuti referen atau sikap ke arah membeli sabun cair dan norma subyektif, menetapkan taraf signifikansi hasil perhitungan di bawah 5\%, serta menetapkan besarnya koefisien determinan. Dua tahapan pertama dilakukan untuk membuktikan hipotesis ketiga sampai kelima yang diajukan di depan.

\section{Analisis Faktor-faktor yang Berpengaruh terhadap Sikap}

Hasil perhitungan untuk menguji ada-tidaknya pengaruh yang positif keyakinan konsumen dan atau evaluasi terhadap sikap konsumen untuk membeli sabun cair merek Lux, Biore atau Lifebuoy (hipotesis ketiga), yang dilakukan dengan model regresi dan koefisien determinannya dapat diringkas seperti yang ditunjukkan pada Tabel 3. 
Tabel 3.

Analisis Regresi dan Koefisien Determinan (Pengaruh Positif Keyakinan dan atau Evaluasi terhadap Sikap)

\begin{tabular}{|c|c|c|c|c|c|c|c|c|c|}
\hline \multirow{2}{*}{$\begin{array}{c}\text { Sikap } \\
\left(A_{b}\right)\end{array}$} & \multicolumn{3}{|c|}{ Lux } & \multicolumn{3}{|c|}{ Biore } & \multicolumn{3}{|c|}{ Lifebuoy } \\
\hline & $\left(b_{i}\right)$ & $\left(e_{i}\right)$ & $r^{2} / R^{2}$ & $\left(b_{i}\right)$ & $\left(e_{i}\right)$ & $r^{2} / R^{2}$ & $\left(b_{i}\right)$ & $\left(e_{i}\right)$ & $r^{2} / R^{2}$ \\
\hline \multicolumn{10}{|c|}{ Penghalus Kulit } \\
\hline 1 & 0.814 & - & 0.080 & $0.365^{\star}$ & - & $0.021^{*}$ & 0.315 & & 0.066 \\
\hline 2 & - & 1.395 & 0.884 & - & $-0.026^{*}$ & $0.000^{*}$ & - & 0.744 & 0.336 \\
\hline 3 & 0.353 & 1.363 & 0.898 & $0.386^{*}$ & $-0.060^{\star}$ & $0.023^{*}$ & 0.300 & 0.737 & 0.396 \\
\hline \multicolumn{10}{|c|}{ Pembersih Kulit } \\
\hline 1 & 0.962 & - & 0.065 & 0.720 & - & 0.042 & -0.190 & - & 0.034 \\
\hline 2 & - & 1.471 & 0.886 & - & $0.123^{*}$ & $0.007^{\star}$ & - & 0.249 & 0.045 \\
\hline 3 & 0.467 & 1.444 & 0.901 & 0.692 & 0.083 & $0.045^{\star}$ & -0.198 & 0.257 & 0.082 \\
\hline \multicolumn{10}{|c|}{ Penyehat Kulit } \\
\hline 1 & 0.375 & - & 0.068 & $-0.169 *$ & - & $0.016^{*}$ & 0.315 & - & 0.066 \\
\hline 2 & - & 1.029 & 0.524 & - & $0.016^{*}$ & $0.000^{\star}$ & - & 0.744 & 0.336 \\
\hline 3 & 0.260 & 1.000 & 0.556 & $-0.173^{*}$ & $0.035^{*}$ & $0.017^{*}$ & 0.300 & 0.737 & 0.396 \\
\hline \multicolumn{10}{|c|}{ Pengharum Kulit } \\
\hline 1 & 0.766 & - & 0.043 & $0.067^{\star}$ & - & $0.000^{*}$ & 0.678 & - & 0.187 \\
\hline 2 & - & 1.455 & 0.883 & - & 1.352 & 0.855 & - & 0.642 & 0.231 \\
\hline 3 & 0.464 & 1.438 & 0.898 & $-0.219^{*}$ & 1.360 & 0.859 & 0.756 & 0.704 & 0.462 \\
\hline \multicolumn{10}{|c|}{ Meningkatkan PD } \\
\hline 1 & 0.802 & - & 0.047 & $0.604^{\star}$ & - & $0.037^{*}$ & 0.835 & - & 0.329 \\
\hline 2 & - & 1.453 & 0.884 & - & 0.655 & 0.248 & - & 0.716 & 0.267 \\
\hline 3 & 0.449 & 1.434 & 0.898 & $0.447^{*}$ & 0.636 & 0.268 & 1.021 & 0.906 & 0.740 \\
\hline \multicolumn{10}{|c|}{ Ekonomis dipakai } \\
\hline 1 & $-0.278^{*}$ & - & $0.040^{*}$ & -0.541 & - & 0.074 & 0.581 & - & 0.136 \\
\hline 2 & - & 0.494 & 0.235 & - & 1.374 & 0.886 & - & 0.656 & 0.244 \\
\hline 3 & $-0.147^{*}$ & 0.473 & 0.246 & -0.170 & 1.349 & 0.893 & 0.699 & 0.735 & 0.436 \\
\hline \multicolumn{10}{|c|}{ Harga murah } \\
\hline 1 & 0.353 & - & 0.078 & $-0.095^{\star}$ & - & $0.005^{\star}$ & $0.077^{*}$ & - & $0.003^{*}$ \\
\hline 2 & - & 0.447 & 0.184 & - & 0.250 & 0.048 & - & 0.409 & 0.075 \\
\hline 3 & 0.386 & 0.465 & 0.277 & $-0.074^{\star}$ & 0.247 & 0.052 & $0.075^{\star}$ & 0.409 & 0.078 \\
\hline \multicolumn{10}{|c|}{ Praktis Dipakai } \\
\hline 1 & $0.074^{\star}$ & - & $0.002^{*}$ & 0.258 & - & 0.036 & 0.727 & - & 0.045 \\
\hline 2 & - & 1.164 & 0.668 & - & $0.181^{*}$ & $0.025^{\star}$ & - & 1.112 & 0.915 \\
\hline 3 & -0.302 & 1.230 & 0.698 & 0.217 & $0.133^{*}$ & $0.049^{*}$ & 0.477 & 1.099 & 0.934 \\
\hline \multicolumn{10}{|c|}{ Praktis Disimpan } \\
\hline 1 & $0.344^{*}$ & - & $0.011^{*}$ & $0.344^{*}$ & - & $0.011^{*}$ & 0.765 & - & 0.038 \\
\hline 2 & - & 1.457 & 0.885 & - & 1.457 & 0.885 & - & 1.104 & 0.918 \\
\hline 3 & 0.350 & 1.457 & 0.896 & 0.350 & 1.457 & 0.896 & 0.525 & 1.094 & 0.936 \\
\hline \multicolumn{10}{|l|}{ Awet } \\
\hline 1 & 0.351 & - & 0.075 & $-0.155^{\star}$ & - & $0.015^{\star}$ & $0.104^{*}$ & - & $0.006^{*}$ \\
\hline 2 & - & 0.452 & 0.190 & - & $0.021^{*}$ & $0.000^{*}$ & - & 0.777 & 0.407 \\
\hline 3 & 0.315 & 0.435 & 0.250 & $-0.158^{*}$ & $0.029^{*}$ & $0.016^{\star}$ & $-0.107^{*}$ & 0.801 & 0.413 \\
\hline
\end{tabular}
Sumber: data primer diolah
(bi) = keyakinan
1, 2, 3 = model regresi sikap (sederhana/ganda)

${ }^{*}$ : Taraf siginifikan $(p)>5 \%$

(ei) = evaluasi

$r^{2} / R^{2}=$ koef determinan sesuai model regresi 
Dari Tabel 3 dapat diketahui bahwa pada sabun cair Lux, keyakinan konsumen memperoleh manfaat ekonomis dipakai dan praktis dipakai mempunyai nilai koefisien negatif, sedangkan yang mempunyai taraf signifikansi (p) lebih besar dari 5\% terdapat pada ekonomis dipakai, praktis dipakai dan praktis disimpan. Dengan demikian pada atribut-atribut manfaat tersebut hipotesis ketiga harus ditolak, yang berarti bahwa tidak ada pengaruh positif keyakinan konsumen terhadap sikap konsumen untuk membeli sabun cair merek Lux. Sementara pada atribut manfaat yang lain hipotesis ketiga dinyatakan gagal ditolak, artinya secara statistika ada pengaruh positif keyakinan konsumen (untuk memperoleh manfaat penghalus kulit, pembersih kulit, penyehat kulit, pengharum kulit, meningkatkan percaya diri, harga yang murah, praktis disimpan, dan awet) terhadap sikap konsumen untuk membeli sabun cair merek Lux.

Adapun pada koefisien evaluasi keyakinan semuanya menunjukkan nilai positif dan taraf signifikansi di bawah 5\%, sehingga hipotesis ketiga untuk semua atribut penting yang ada dikatakan gagal ditolak. Hal itu berarti secara statistika dapat disimpulkan bahwa ada pengaruh positif evaluasi keyakinan konsumen terhadap sikap konsumen untuk membeli sabun cair merek Lux.

Apabila keyakinan konsumen dan evaluasi dipadukan ternyata hipotesis ketiga yang ditolak hanya atribut manfaat ekonomis dipakai (koefisien variabel keyakinan negatif dan $p>5 \%$ ) dan praktis dipakai (koefisien variabel keyakinan negatif), atau berarti tidak ada pengaruh positif keyakinan konsumen dan evaluasi keyakinan terhadap sikap konsumen sabun cair merek Lux. Sedangkan hipotesis ketiga untuk atribut yang lain gagal ditolak atau pada kaadaan signifikan.

Dengan mendasarkan pada pembuktian hipotesis ketiga di atas dan kemudian merujuk pada hasil koefisien determinan, maka dapat dicermati pula bahwa jika hanya dilihat dari sisi keyakinan konsumen saja, maka proporsi sikap konsumen yang terjelaskan oleh faktor tersebut senantiasa diperoleh hasil yang rendah. Proporsi nilai tersebut jauh lebih rendah dibandingkan jika hanya faktor evaluasi keyakinan saja yang ditetapkan berpengaruh terhadap sikap konsumen. Bahkan kalau kedua faktor (keyakinan konsumen dan evaluasi) dipadukan untuk melihat pengaruhnya terhadap sikap, perubahan koefisien determinannya tidak cukup bermakna. Artinya bahwa untuk merek sabun cair Lux, sesungguhnya yang banyak berpengaruh terhadap sikap konsumen adalah evaluasinya, bukan keyakinan konsumen untuk memperoleh atribut manfaat membeli sabun cair Lux. Karena itu atribut sabun cair yang dianggap sangat berarti bagi konsumen terutama sebagai pembersih kulit, praktis disimpan, penghalus kulit, meningkatkan kepercayaan diri, dan pengharum kulit. 
Pada sabun cair merek Biore, hasil penelitian menunjukkan bahwa nilai koefisien yang negatif dan atau yang mempunyai taraf signifikansi lebih besar dari $5 \%$ tersebar hampir di semua atribut manfaat yang diyakini dapat diperoleh konsumen pembeli sabun cair Biore, kecuali untuk atribut manfaat pembersih kulit dan praktis dipakai. Dengan kata lain, hipotesis ketiga untuk kedelapan atribut yang lain dinyatakan ditolak, artinya bahwa tidak ada pengaruh positif keyakinan konsumen terhadap sikap mereka untuk membeli sabun cair merek Biore. Sedangkan untuk atribut manfaat pembersih kulit dan praktis dipakai terjadi sebaliknya. Secara statistika untuk dua atribut tersebut hipotesis ketiga gagal ditolak, yang berarti ada pengaruh positif keyakinan konsumen terhadap sikap mereka untuk membeli sabun cair merek Biore.

Meskipun tidak sebanyak yang terjadi pada keyakinan konsumen, pada evaluasi konsumen terdapat lima atribut penting yang mempunyai nilai koefisien negatif dan atau dengan taraf signifikansi lebih besar dari $5 \%$, yaitu pada atribut penghalus kulit, pembersih kulit, penyehat kulit, praktis dipakai dan awet. Karenanya untuk atribut-atribut tersebut hipotesis ketiga harus ditolak, artinya tidak ada pengaruh positif evaluasi konsumen terhadap sikap mereka untuk membeli sabun cair merek Biore. Sebaliknya untuk lima atribut yang lain dapat disimpulkan bahwa hipotesis ketiga gagal ditolak, sehingga untuk kelima atribut tersebut dinyatakan ada pengaruh positif evaluasi konsumen terhadap sikap mereka untuk membeli sabun cair merek Biore.

Untuk model regresi dengan perpaduan faktor keyakinan konsumen dan evaluasi sebagai variabel bebas terhadap sikap mereka untuk membeli sabun cair Biore ternyata hanya atribut praktis disimpan saja yang dapat menghasilkan hipotesis ketiga yang signifikan. Sementara untuk sembilan atribut yang lain hipotesis ketiga harus ditolak, yang berarti pada kesembilan atribut tersebut keyakinan konsumen dan evaluasi keyakinannya dinyatakan tidak mempunyai pengaruh positif terhadap sikap mereka pada sabun cair merek Biore.

Apabila prosedur pembuktian hipotesis ketiga di atas dan dikaitkan dengan hasil perhitungan koefisien determinan, maka dapat diketahui bahwa kalau hanya dilihat dari sisi evaluasi konsumen saja, maka proporsi sikap konsumen yang dapat dijelaskan oleh faktor tersebut hampir semuanya bisa diperoleh dengan hasil yang tinggi, terutama yang terlihat pada atribut pengharum kulit, ekonomis dipakai dan praktis disimpan. Proporsi nilai tersebut jauh lebih tinggi dibandingkan jika hanya variabel keyakinan saja yang ditetapkan berpengaruh terhadap sikap konsumen. Bahkan kalau kedua faktor (keyakinan konsumen dan evaluasi keyakinan) dipadukan untuk melihat pengaruhnya terhadap sikap, pertambahan nilai yang dapat menjelaskan sikap konsumen tersebut tidak berubah dengan 
cukup besar. Artinya bahwa pada merek sabun cair Biore, ternyata yang banyak berpengaruh terhadap sikap konsumen adalah evaluasi keyakinannya, bukan keyakinan konsumen untuk memperoleh atribut manfaat dalam membeli sabun cair Biore.

Adapun pada sabun cair Lifebuoy, dapat diketahui bahwa keyakinan konsumen dapat memperoleh manfaat sabun cair Lifebuoy sebagai pembersih kulit mempunyai nilai koefisien negatif, sedangkan yang mempunyai taraf signifikansi (p) lebih besar dari 5\% terdapat pada harga yang murah dan awet. Sehingga dapat dinyatakan pada atribut-atribut tersebut hipotesis ketiga harus ditolak, yang berarti bahwa tidak ada pengaruh positif keyakinan konsumen terhadap sikap konsumen untuk membeli sabun cair merek Lifebuoy. Sedangkan pada ketujuh atribut yang lain hipotesis ketiga disimpulkan gagal ditolak, artinya secara statistika untuk atribut manfaat penghalus kulit, penyehat kulit, pengharum kulit, meningkatkan percaya diri, ekonomis dipakai, praktis dipakai dan praktis disimpan dikatakan ada pengaruh positif keyakinan konsumen terhadap sikap mereka.

Sementara itu jika dilihat dari koefisien variabel evaluasi terlihat bahwa pada semua atribut menunjukkan nilai positif dan taraf signifikansi di bawah 5\%, sehingga hipotesis ketiga untuk semua atribut penting tersebut dikatakan gagal ditolak. Hal itu berarti bahwa secara statistika disimpulkan ada pengaruh positif evaluasi keyakinan konsumen terhadap sikap konsumen untuk membeli sabun cair merek Lifebuoy.

Peninjauan model regresi dengan perpaduan variabel bebas keyakinan konsumen dan evaluasi terhadap sikap mereka dalam membeli sabun cair Lifebuoy ternyata menghasilkan hipotesis ketiga yang tidak signifikan untuk atribut pembersih kulit, harga yang murah dan awet. Berarti untuk ketiga atribut tersebut dinyatakan tidak ada pengaruh positif keyakinan konsumen dan evaluasi terhadap sikap konsumen dalam membeli sabun cair merek Lifebuoy, sedangkan hipotesis ketiga untuk atribut yang lain gagal ditolak atau pada kaadaan signifikan.

Dari pembuktian hipotesis ketiga di atas dan kemudian merujuk pada hasil koefisien determinan yang diperoleh, maka dapat diketahui bahwa untuk atribut penghalus kulit, penyehat kulit, pengharum kulit, meningkatkan percaya diri dan ekonomis dipakai, perlakuan memadukan dua faktor keyakinan konsumen dan evaluasi untuk menjelaskan sikap konsumen dapat menghasilkan nilai yang cukup tinggi dibandingkan kalau model regresi sikapnya hanya dibentuk oleh satu faktor keyakinan konsumen atau evaluasi saja. Sedangkan untuk atribut praktis dipakai dan praktis disimpan dengan hanya menggunakan faktor evaluasi saja sudah cukup tinggi memberikan proporsi yang dapat menjelaskan sikap konsumen. Bahkan jika model regresi ditambah dengan faktor keyakinan konsumen, hasil nilai proporsi dari kedua faktor tersebut tidak bertambah se- 
cara cukup bermakna. Adapun jika hanya dilihat dari sisi keyakinan konsumen saja, maka proporsi sikap konsumen yang terjelaskan oleh faktor tersebut umumnya diperoleh hasil yang jauh lebih rendah dibandingkan dengan model regresi yang lain, kecuali pada atribut meningkatkan percaya diri.

Secara umum hasil penelitian yang ditunjukkan oleh Tabel 3 memberikan pengertian bahwa pertama, faktor keyakinan konsumen pada sabun cair Lux dan Lifebuoy pada umumnya mempunyai pengaruh positif terhadap sikap konsumen, kecuali pada Lux untuk atribut manfaat ekonomis dipakai, praktis dipakai dan praktis disimpan, serta pada Lifebuoy untuk pembersih kulit, harga murah dan pemakaian yang awet. Kondisi sangat berbeda terjadi untuk sabun cair Biore, karena faktor keyakinan konsumen pada sabun cair merek ini justru tidak berpengaruh positif terhadap sikap konsumen, kecuali untuk pembersih kulit, praktis dipakai dan praktis disimpan.

Kedua, faktor evaluasi pada sabun cair merek Lux dan Lifebuoy semuanya memberi pengaruh positif terhadap sikap konsumen, sedangkan pada Biore hanya sebagian saja. Ketiga, umumnya faktor evaluasi mampu memberikan proporsi yang jauh lebih besar dalam menjelaskan sikap konsumen dibandingkan dengan hanya faktor keyakinan konsumen saja, kecuali terjadi hal yang sebaliknya khusus untuk atribut manfaat meningkatkan percaya diri pada sabun cair merek Lifebuoy. Dengan kata lain, secara umum faktor evaluasi keyakinan merupakan kontributor utama dalam pembentukan sikap konsumen.

\section{Analisis Faktor-faktor yang Berpengaruh terhadap Norma Subyektif}

Pengujian ada-tidaknya pengaruh positif keyakinan normatif dan motivasi terhadap norma subyektif konsumen dalam membeli sabun cair merek Lux, Biore, atau Lifebuoy (hipotesis keempat) dengan pendekatan regresi dan koefisien determinannya didasarkan pada ringkasan hasil perhitungan yang ditunjukkan pada Tabel 4 .

Tabel 4 memberikan informasi bahwa untuk sabun cair merek Lux, faktor keyakinan normatif dan motivasi mengikuti referen, baik secara sendiri maupun bersama-sama semuanya menunjukkan nilai positif dan taraf signifikansi di bawah 5\%, sehingga hipotesis keempat untuk semua referen penting yang ada dikatakan gagal ditolak. Hal itu berarti secara statistika dapat disimpulkan bahwa ada pengaruh positif keyakinan normatif dan motivasi mengikuti referen terhadap norma subyektif konsumen untuk membeli sabun cair merek Lux.

Dari pembuktian hipotesis keempat tersebut dan kemudian merujuk pada hasil koefisien determinan, maka dapat dicermati bahwa jika hanya dilihat dari sisi keyakinan normatif saja, maka proporsi norma 
subyektif konsumen yang terjelaskan oleh faktor tersebut senantiasa diperoleh hasil yang lebih tinggi dibandingkan jika faktor motivasi mengikuti referen saja yang mempengaruhi norma subyektif, kecuali untuk referen dari rekan sekerja. Namun proporsi yang paling baik adalah jika kedua faktor tersebut dipadukan untuk mempengaruhi norma subyektif, karena peningkatan proporsinya dapat menghasilkan nilai yang sangat bermakna.

Tabel 4:

Hasil Persamaan Regresi Linear

(Pengaruh Positif Keyakinan Normatif dan Motivasi terhadap Norma Subyektif)

\begin{tabular}{|c|c|c|c|c|c|c|c|c|c|}
\hline \multirow{2}{*}{$\begin{array}{l}\text { Norma Subyektif } \\
\text { (SN) }\end{array}$} & \multicolumn{3}{|c|}{ Lux } & \multicolumn{3}{|c|}{ Biore } & \multicolumn{3}{|c|}{ Lifebuoy } \\
\hline & $\left(\mathrm{NB}_{\mathrm{j}}\right)$ & $\left(\mathrm{MC}_{\mathrm{j}}\right)$ & $\mathrm{r}^{2} / \mathrm{R}^{2}$ & $\left(\mathrm{NB}_{\mathrm{j}}\right)$ & $\left(\mathrm{MC}_{\mathrm{j}}\right)$ & $\mathrm{r}^{2} / \mathrm{R}^{2}$ & $\left(\mathrm{NB}_{\mathrm{j}}\right)$ & $\left(\mathrm{MC}_{\mathrm{j}}\right)$ & $\mathrm{r}^{2} / \mathrm{R}^{2}$ \\
\hline \multicolumn{10}{|l|}{ Keluarga } \\
\hline 1 & 0.708 & - & 0.235 & 0.574 & - & 0.152 & 0.592 & - & 0.162 \\
\hline 2 & - & 0.451 & 0.101 & 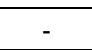 & -0.556 & 0.161 & - & -0.490 & 0.115 \\
\hline 3 & 0.694 & 0.429 & 0.327 & 0.470 & -0.462 & 0.258 & 0.688 & -0.597 & 0.329 \\
\hline \multicolumn{10}{|l|}{ Teman Dekat } \\
\hline 1 & 0.655 & - & 0.266 & 0.930 & - & 0.452 & 0.453 & - & 0.130 \\
\hline 2 & - & 0.417 & 0.090 & - & 0.553 & 0.164 & - & -0.330 & 0.068 \\
\hline 3 & 0.697 & 0.489 & 0.388 & 1.206 & 0.909 & 0.856 & 0.454 & -0.331 & 0.199 \\
\hline \multicolumn{10}{|l|}{ Rekan Kerja } \\
\hline 1 & 0.601 & - & 0.159 & 0.962 & - & 0.328 & 0.621 & - & 0.140 \\
\hline 2 & - & 0.435 & 0.164 & - & 0.544 & 0.163 & - & -0.565 & 0.168 \\
\hline 3 & 0.515 & 0.375 & 0.278 & 1.105 & 0.692 & 0.584 & 0.859 & -0.753 & 0.417 \\
\hline \multicolumn{10}{|l|}{ Dokter Kulit } \\
\hline 1 & 0.549 & - & 0.176 & 0.358 & - & 0.062 & 0.390 & - & 0.101 \\
\hline 2 & - & 0.367 & 0.111 & - & -0.648 & 0.248 & - & -0.259 & 0.045 \\
\hline 3 & 0.523 & 0.339 & 0.270 & $0.209^{\star}$ & -0.606 & 0.268 & 0.381 & -0.244 & 0.141 \\
\hline
\end{tabular}

Sumber: data primer diolah

* : Taraf siginifikan $(p)>5 \%$

$\left(\mathrm{NB}_{\mathrm{j}}\right)=$ keyakinan normative

1, 2, 3 = model regresi sikap (sederhana/ganda

$\left(\mathrm{MC}_{\mathrm{j}}\right)=$ motivasi

$r^{2} / R^{2}=$ koef determinan sesuai model regresi

Bagi konsumen sabun cair merek Biore, keyakinan normatif nampaknya menjadi pertimbangan norma subyektifnya. Hal itu dapat dilihat dari koefisien faktor tersebut yang menunjukkan nilai positif dan taraf signifikansi di bawah 5\%. Karena itu, hipotesis keempat untuk referen keluarga, teman dekat, rekan kerja dan dokter kulit dinyatakan gagal ditolak. Hal itu berarti secara statistika dapat disimpulkan bahwa ada pengaruh positif keyakinan normatif referen terhadap norma subyektif konsumen untuk membeli sabun cair merek Biore. 
Adapun dari keempat referen penting yang ada, ternyata motivasi konsumen untuk mengikuti referen menghasilkan kondisi yang seimbang dalam mempengaruhi norma subyektif. Hal ini ditunjukan oleh koefisien negatif faktor tersebut pada referen keluarga dan dokter kulit, sehingga untuk kedua referen tersebut hipotesis keempat disimpulkan harus ditolak, artinya tidak ada pengaruh positif motivasi konsumen untuk mengikuti referen terhadap norma subyektif konsumen. Sebaliknya yang terjadi pada referen teman dekat dan rekan sekerja, motivasi konsumen menunjukkan nilai yang positif dan taraf signifikansi di bawah $5 \%$, sehingga dapat dikatakan hipotesis keempat gagal ditolak, yang berarti bahwa secara statistika dapat disimpulkan ada pengaruh positif motivasi konssumen untuk mengikuti referen terhadap norma subyektif konsumen untuk membeli sabun cair merek Biore.

Simpulan pengujian hipotesis untuk faktor motivasi konsumen mengikuti referen tersebut menunjukkan kondisi yang sama jika faktor tersebut dipadukan dengan keyakinan normatif konsumen. Dengan kata lain, pada referen keluarga dan dokter kulit disimpulkan bahwa secara statistika dinyatakan tidak ada pengaruh positif keyakinan normatif dan motivasi konsumen untuk mengikuti referen secara serentak terhadap norma subyektif konsumen. Sedangkan pada referen teman dekat dan rekan kerja kondisinya terjadi yang sebaliknya, yaitu hipotesis keempat gagal ditolak.

Dengan mendasarkan pada pembuktian hipotesis keempat di atas dan kemudian merujuk pada hasil koefisien determinan dapat diketahui pula bahwa jika hanya dilihat dari satu faktor saja, maka yang banyak memberi kontribusi kepada norma subyektif adalah faktor keyakinan normatif, terutama pada referen teman dekat dan rekan kerja. Tetapi proporsi nilai yang dapat menjelaskan norma subyektif akan lebih tinggi (baik) lagi jika faktor keyakinan normatif dipadukan dengan faktor motivasi konsumen untuk mengikuti referen.

Pada sabun cair merek Lifebuoy, faktor keyakinan normatif semuanya menunjukkan nilai positif dan taraf signifikansi di bawah $5 \%$, sehingga hipotesis keempat untuk semua referen penting yang ada dikatakan gagal ditolak. Hal itu berarti secara statistika dapat disimpulkan bahwa ada pengaruh positif keyakinan normatif terhadap norma subyektif konsumen untuk membeli sabun cair merek Lifebuoy.

Sementara itu untuk faktor motivasi konsumen mengikuti referen terjadi hal yang sebaliknya, koefisien faktor itu menunjukkan nilai yang negatif pada semua referen, sehingga meskipun taraf signifikansinya di bawah 5\%, maka hipotesis keempat disimpulkan untuk ditolak. Simpulan yang sama juga terjadi apabila faktor itu dipadukan dengan keyakinan normatif. Dengan kata lain, disimpulkan tidak ada pengaruh positif keyakinan normatif dan motivasi konsumen mengikuti referen secara bersama-sama 
terhadap norma subyektif konsumen untuk membeli sabun cair merek Lifebuoy.

Dengan merujuk pada hasil pengujian hipotesis tersebut di atas dan koefisien determinan, maka dapat dinyatakan bahwa kontribusi norma subyektif konsumen sabun cair Lifebuoy ditentukan oleh faktor keyakinan normatif mereka, bukan oleh motivasi konsumen mengikuti referen keluarga, teman dekat, rekan kerja atau dokter kulit.

Secara umum hasil penelitian yang ditunjukkan oleh Tabel 4 untuk sabun cair Lux, Biore dan Lifebuoy dapat disimpulkan pertama, faktor keyakinan normatif konsumen pada semua referennya semua referen mempunyai pengaruh positif terhadap norma subyektif konsumen, kecuali pada sabun Biore untuk referen dokter kulit. Kedua, faktor motivasi konsumen mengikuti referen menunjukkan hasil yang saling berbeda untuk ketiga merek sabun cair yang ada. Norma subyektif konsumen sabun Lux dipengaruhi secara positif oleh motivasi konsumen mengikuti semua referen, sabun Biore hanya oleh referen teman dekat dan rekan kerja, sedangkan pada sabun Lifebuoy semua referen tidak berpengaruh positif memotivasi konsumen dalam membentuk norma subyektif.

Ketiga, umumnya faktor keyakinan normatif mampu memberikan proporsi yang lebih besar dalam menjelaskan norma subyektif konsumen dibandingkan dengan faktor motivasi konsumen mengikuti referen, kecuali terjadi hal yang sebaliknya khusus untuk referen rekan kerja pada sabun cair merek Lux. Dengan kata lain, secara umum faktor keyakinan normatif cenderung mempunyai arah yang sama dengan norma subyektif konsumen dibandingkan dengan faktor motivasi konsumen mengikuti referen. Meskipun demikian, untuk sabun cair merek Lux dan Biore proporsi yang jauh lebih besar dalam menjelaskan norma subyektif konsumen dapat diperoleh jika keyakinan normatif dipadukan dengan motivasi konsumen mengikuti referen.

\section{Analisis Faktor-faktor yang Berpengaruh terhadap Minat}

Hasil perhitungan untuk menguji ada-tidaknya pengaruh yang positif sikap dan atau norma subyektif terhadap minat konsumen untuk membeli sabun cair merek Lux, Biore atau Lifebuoy (hipotesis kelima), yang dilakukan dengan model regresi dan koefisien determinannya dapat diringkas seperti yang ditunjukkan pada Tabel 5.

Dari Tabel 5 secara umum dapat diperoleh informasi hasil penelitian bagi sabun cair merek Lux, Biore dan Lifebuoy. dilihat dari nilai negatif koefisien faktor sikap dan norma subyektif serta taraf signifikansi yang lebih besar dari 5\%, maka bisa disimpulkan hipotesis kelima semuanya ditolak. Artinya tidak ada pengaruh positif sikap dan norma subyektif terhadap minat konsumen untuk membeli sabun cair yang ada. 
Kekecualian hanya terjadi untuk sabun Lux, yaitu adanya pengaruh positif norma subyektif terhadap minat konsumen. Namun proporsi norma subyektif tersebut untuk dapat menjelaskan minat konsumen sungguh tidak bermakna, yaitu hanya sebesar $4.2 \%$, sedangkan sebanyak $95,8 \%$ dominan dipengaruhi oleh faktor-faktor lain yang belum teridentifikasi dalam penelitian ini.

Tabel 5.

Analisis Regresi dan Koefisien Determinan

(Pengaruh Positif Sikap dan Norma Subyektif terhadap Minat)

\begin{tabular}{|c|c|c|c|c|c|c|c|c|c|}
\hline \multirow{2}{*}{$\begin{array}{l}\text { Minat } \\
\text { Berperilaku } \\
\text { (BI) }\end{array}$} & \multicolumn{3}{|c|}{ Lux } & \multicolumn{3}{|c|}{ Biore } & \multicolumn{3}{|c|}{ Lifebuoy } \\
\hline & (A) & (SN) & $r^{2} / R^{2}$ & (A) & (SN) & $r^{2} / R^{2}$ & (A) & (SN) & $r^{2} / R^{2}$ \\
\hline 1 & $0.0035^{\star}$ & - & $0.001^{*}$ & $-0.0019^{\star}$ & - & $0.000^{*}$ & $0.0145^{\star}$ & - & $0.011^{*}$ \\
\hline 2 & - & 0.051 & 0.042 & - & $0.027^{*}$ & $0.015^{\star}$ & - & $0.0235^{\star}$ & $0.009^{*}$ \\
\hline 3 & $-0.0138^{*}$ & 0.058 & $0.050^{*}$ & $-0.0037^{*}$ & $0.0275^{*}$ & $0.016^{*}$ & $0.0132^{*}$ & $0.0209^{*}$ & $0.018^{\star}$ \\
\hline
\end{tabular}

Sumber: data primer diolah

$*$ : Taraf siginifikan $(p)>5 \%$

(A) = sikap

1,2,3 = model regresi sikap (sederhana/ganda)

$(\mathrm{SN})=$ norma subyektif

$r^{2} / R^{2}=$ koef determinan sesuai model regresi

\section{REKOMENDASI}

Berdasarkan pada hasil dan pembahasan di atas, maka dapat diberikan beberapa rekomendasi terutama kepada manajemen sabun cair merek Lux, Biore dan Lifebuoy sebagai berikut:

1. Dengan tidak adanya pengaruh positif dari sikap dan atau norma subyektif terhadap minat konsumen untuk membeli sabun cair merek Lux, Biore dan atau Lifebuoy memberi petunjuk bahwa apabila produsen dalam melaksanakan kebijakan pemasarannya mengacu kepada model tersebut (Reasoned Action Model), mereka sungguhsungguh perlu berusaha untuk meningkatkan lebih baik lagi sikap dan norma subyektif konsumen yang lebih mengarah dan dapat berguna untuk mendukung minat beli konsumen.

2. Hasil pengujian ada-tidaknya pengaruh positif dari keyakinan konsumen dan atau evaluasi terhadap sikap konsumen menunjukkan bahwa faktor evaluasi lebih dominan berpengaruh positif dibandingkan dengan keyakinan konsumen, kecuali untuk manfaat yang dapat meningkatkan kepercayaan diri pada sabun Lifebuoy. Hal itu memberi arti bahwa konsumen masih merasakan atribut sabun cair yang dipunyai masing-masing merek belum diyakini sebagai atribut unik (khas) dari 
merek yang bersangkutan, melainkan hanya sebagai atribut generik (umum) yang semua merek dapat mempunyainya.

Karena itu, masing-masing merek masih perlu berusaha mengintensifkan program dan kegiatan pemasaran yang lebih mengarah pada kekhususan atribut yang ditawarkan dan yang dapat diperoleh konsumen, sehingga keyakinan konsumen dalam memperoleh manfaat penggunaan merek dapat meningkatkan sikapnya untuk membeli. Misalnya sabun Lux cair dapat dieksploitasi dari sisi atribut penghalus kulit sebagai bentuk konsistensi dari sabun Lux batangan/padat yang selama ini telah dipersepsikan sebagai sabun yang dapat menghaluskan kulit. Sedangkan pada sabun cair Lifebuoy lebih menekankan pada sisi pembersih dan penyehat kulit, selain meningkatkan kepercayaan diri konsumen.

Adapun untuk membedakan dengan karakteristik jenis sabun batangan, maka ketiga produsen sabun cair tersebut dapat menonjolkan segi kepraktisan penyimpanan sabun cair dengan mendesain kemasan produk yang menarik dan sesuai dengan variasi serta ukuran produk yang diinginkan konsumen.

3. Simpulan dari ada-tidaknya pengaruh positif dari keyakinan normatif konsumen dan atau motivasi untuk mengikuti referen terhadap norma subyektif dapat menimbulkan perlakuan yang berbeda-beda. Bagi Lux yang keyakinan normatif konsumen telah ditindaklanjuti dengan motivasi untuk mengikuti semua referen, maka tugas manajemen mungkin hanya perlu meningkatkan usaha mendekati referen dengan lebih baik lagi, karena konsumen seringkali mengidentifikasikan perilakunya dengan kelompok referennya, sehingga pengaruh kedua faktor tersebut dapat lebih banyak menyumbang pengaruh terhadap norma subyektif Sedangkan bagi produsen Biore perlu usaha yang lebih keras lagi, terutama untuk mempengaruhi keluarga dan dokter kulit dari segmen pasar yang dituju. Dan usaha yang paling keras perlu dilakukan oleh produsen Lifebuoy, karena meskipun konsumen telah mempunyai keyakinan normatif tetapi tanpa dibarengi dengan motivasi untuk mengikuti semua referen. Hal ini dipandang perlu untuk dilakukan, sehingga apabila eksploitasi kegiatan pemasaran dari sisi keyakinan normatif yang diikuti dengan motivasi konsumen untuk mengikuti referen ini dapat dilakukan dengan baik dan mencapai sasaran, maka akan sangat membantu produsen dalam mengenalkan, mempromosikan dan mendorong pembelian produk oleh konsumen.

4. Analisis yang dilakukan kepada semua faktor pembentuk minat beli konsumen menunjukkan bahwa konsumen yang sama memberikan nilai kepada sabun cair Lux yang selalu lebih baik/tinggi dibandingkan dengan penilaian mereka kepada Biore dan Lifebuoy. Hasil tersebut 
dapat memberi pelajaran bagi produsen Biore dan Lifebuoy kemungkinan perlunya dilakukan pengkajian kebijakan pemasaran yang telah dilakukan oleh produsen sabun Lux untuk melakukan hal yang sama, atau sebaliknya melakukan antisipasi kegiatan yang inovatif dan yang dapat mendorong meningkatnya penilaian faktor-faktor pembentuk minat beli konsumennya.

\section{DAFTAR PUSTAKA}

Albari (1998), Perilaku Konsumen Dalam membeli Ayam Goreng, Laporan Penelitian, Yogyakarta: Pusat Pengembangan Manajemen FE UII (1999), Sikap Konsumen Dalam Membeli Ayam Goreng di Yogyakarta, Laporan Penelitian, Yogyakarta: Lembaga Penelitian UII (1999), "Sikap Konsumen: Pemilihan Model dan Penelitiannya," Jurnal Siasat Bisnis, 4 (7): 51-64.

Alvin, A.A. (1993), "The Future Challenge to Market Research," Marketing Research, 5 (2): 12-19.

Ancok, Dj. (1989), "Validitas dan Reliabilitas Instrumen Penelitian," dalam Masri Singarimbun dan Sofian Effendi (ed.), Metode Penelitian Survei, Jakarta: LP3ES, h. 122-146.

Assael, H. (1992), Consumer Behavior and Marketing Action, $4^{\text {th }}$ ed Boston: PWS-KENT Publishing Company.

Bentler, P.M. and George Speckart (1979), "Models of Attitude-Behavior Relations," Psychological Review, 86 (5): 452-464.

Bleckwell, R.D., P.W. Miniard and J.F. Engel (2001), Consumer behavior, $9^{\text {th }}$ ed., Orlando: Hourcourt College Publishers.

Blythe, J. (1997), The Essence of Consumer Behavior, London: Prentice Hall.

Bowerman, B.L., R.T. O'Connell and L.L. Hand (2001), Business Statistics in Practice, $2^{\text {th }}$ ed., New York: The McGrow-Hill Companies, Inc.

Dharmmesta, B.S. (1992), "Riset Tentang Minat dan Perilaku Konsumen," Jurnal Ekonomi dan Bisnis, 7 (1): 39-53

(1994),"Perilaku Konsumen Indonesia Tahun 2000," Kelola Gadjah Mada University Business Review, 3 (6-Mei): 39-53 
(1997). "Keputusan-keputusan Strategik Untuk Mengeksplorasi Sikap dan Perilaku Konsumen," Jurnal Ekonomi dan Bisnis Indonesia, 12 (3): 1-19

Daneshvary, R. and R.K. Schwer (2000), "The Association Endorsement and Consumers' Intention to Purchase," The Journal of Consumer Marketing, 17 (3): 203-213.

Darrel, E. et al. (1994), "Typical Definition of 'Satisfaction' is Too Limited," Marketing News, 28 (1): 6-8

East, R. (1997), Consumer Behaviour: Advances and Applications in Marketing, London: Prentice Hall.

Effendi, S. (1989), "Prinsip-Prinsip Pengukuran dan Penyusunan Skala," dalam Masri Singarimbun dan Sofian Effendi (ed.), Metode Penelitian Survei, Jakarta: LP3ES, h. 95-121.

Fishbein, M and I. Ajzen (1975), Belief, Attitude, Intention and Behavior, Reading, Mass.: Addison-Wesley Publishing Co.

Foxall, G., R. Goldsmith and S. Brown (1998), Consumer Psychology for Marketing, $2^{\text {th }}$ ed., London: International Thomson Business Press.

Haerani, S. (1993), Sikap Konsumen terhadap Menabung di Kotamadya Ujungpandang, Tesis Magister Sains (tidak dipublikasikan), Yogyakarta: Program Pasca Sarjana UGM.

Hawkins, D.L., R.J. Best and K.A. Coney (2001), Consumer Behavior: Building Marketing Strategy, $8^{\text {th }}$ ed. New York: McGraw-Hill Companies.

Kardes, F.R. (1999), Consumer Behavior and Managerial Decision Making, Massachussetts: Addison-Wesley Educational Publishers, Inc.

Kasali, R.. (1992), Manajemen Periklanan, Konsep dan Aplikasinya di Indonesia, Jakarta: Pustaka Utama Grafiti

Kerlinger, F.N. (1992), Asas-asas Penelitian Behavioral, Edisi Ketiga, Yogyakarta: Gadjah Mada University Press.

Kinnear, T.C. and James R. Taylor (1992), Riset Pemasaran: Pendekatan Terpadu (Jilid 1), Edisi Ketiga, Jakarta: Erlangga.

Kotler, P. (2003), Marketing Management, $11^{\text {th }}$ ed., New Jersey: Prentice Hall 
Kristianto, P.L. (1994), Analisis Sikap Konsumen terhadap Minat Membeli Sepeda Motor Bebek Merek Honda di Kodya Yogyakarta, Tesis Magister Sains (tidak dipublikasikan), Yogyakarta: Program Pasca Sarjana UGM.

Lilien, G.L., P. Kotler, and K.S. Moorthy (1992), Marketing Models, New Jersey: Prentice Hall, Englewood Cliffs.

Loudon, D.L. and A.J. Della Bitta (1993), Consumer Behavior: Concept and Applications, $4^{\text {th }}$ ed. New York: McGraw-Hill, Inc.

Malhotra, N.K. (1999), Marketing Research: An Apllied Orientation, $3^{\text {th }}$ ed., New Jersey: Prentice Hall International, Inc.

Mangkunegara, A. A. (1988), Perilaku Konsumen, Bandung: PT Eresco

Manopol, Y. (2001), "Licinnya Persaingan Sabun Cair," SWA, 18 (24; 22 November-2 Desember): 80-81.

Mittal, B. (1994), "Public Assessment of TV Advertising: Faint Praise and Harsh Criticism," Journal of Advertising Research, 34 (1): 35-54.

Moven, J.C. and M. Minor (1998), Consumer Behavior, $5^{\text {th }}$ ed., New Jersey: Prentice Hall International, Inc.

Newbolt, P. (1995), Statistics for Business \& Economics, $4^{\text {th }}$ ed., New Jersey: Prentice-Hall International, Inc.

Ohanian, R. (1991), "The Impact of Celebrity Spokespersons' Perceived Image on Consumers' Intention to Purchase," Journal of Advertising Research, February/March: 46-54.

Peter, J.P. and J.C. Olson (1996), Consumer Behavior and Marketing Strategy, $4^{\text {th }}$ ed., Chicago: Richard D. Irwin, Inc.

Pride, W. M. dan O. C. Ferrell (1995), Pemasaran: Teori dan Praktek sehari-hari (Jilid 1), Edisi Ketujuh, Jakarta: Binarupa Aksara.

Schiffman, L.G. and L.L. Kanuk (1997), Consumer Behavior, 6th ed., New Jersey: Prentice Hall International, Inc.

Sekaran, U. (2000), Research Methods for Business, $3^{\text {th }}$ ed., New York: John Wiley \& Sons, Inc.

Solomon, M.R. (1999), Consumer Behavior, $4^{\text {th }}$ ed., New Jersey: Prentice Hall, Inc.

Stanton, W.J. (1993), Prinsip Pemasaran (Jilid 1), Edisi Ketujuh, Jakarta: Erlangga. 
Swastha, B.D. dan Irawan (1997), Manajemen Pemasaran Modern, Edisi Kedua, Jakarta: Erlangga

Swastha, B.D. dan T.H. Handoko (1987), Manajemen Pemasaran: Analisa Perilaku Konsumen, Yogyakarta: Liberty.

Till, B.D. and M. Busler (2000), "The Match-Up Hypothesis: Physical Attractiveness, Expertise, and the Role of Fit on Brand Attitude, Purchase Intent and Brand Beliefs," The Journal of Advertising, 29 (3): 1-13.

Wardani, D. (1994), Analisis Perilaku Konsumen Terhadap Pembelian Produk Bergaransi Mixer Comb. Merek Philips, Tesis Magister Sains (tidak dipublikasikan), Yogyakarta: Program Pasca Sarjana UGM.

Welkowitz,J., R.B. Ewen and J. Cohen (2000), Introductory Statistics for the Behavioral Sciences, $5^{\text {th }}$ ed., Orlando: Harcourt Brace \& Company.

Wells, W.D. and D. Prensky (1996), Consumer Behavior, New York: John Wiley \& Sons, Inc.

Zikmund, W.G. (1997), Business Research Methods, $5^{\text {th }}$ ed., Orlando: The Dryden Press. 